looking for the meaning of immram or rapparee, for instance, will find valuable information, and these are two items selected at random which are very important if we are to understand part of the Irish past. The same could be said of other terms or expressions related to contemporary Ireland found in the dictionary: gallowglass, hooker, sash, ivy, B-specials, England's difficulty, etc. All of them are present in contemporary Irish literature and one wonders about the reader's understanding of the text without a knowledge of their specific implications.

In one way, Diccionario cultural e histórico de Irlanda and Robert Welch's The Oxford Companion to Irish Literature also published in 1996 are complementary. As we can gather from the title their scope is different but $I$ think that the first is more ambitious and valuable for everyone in Spain who is not acquainted with Ireland's rich culture. Apart from providing a great amount of necessary information about historic feats and events, the dictionary also gives detailed references of authors and their output, which makes it very useful. Two little things one would like to add. First, there is no mention of The Freeman's Journal (1763-1923), whereas less important journals are registered, and secondly, there are two items, Molly Bloom and Anna Livia, which stand for the only fictional characters included in the dictionary and one does not exactly know why only these two were selected when there is no mention of any others.

The Diccionario cultural e histórico de Irlanda is a very valuable book which comes to fill a place in Irish studies, and I am sure it will benefit to those interested in Ireland. It is a landmark in Spain for the popularisation of Irish culture and it provides encouragement for those who have already started contributing to a better knowledge of Ireland and her culture in Spain.

Antonio Raúl de Toro Santos

\title{
Ronald Carter and John McRae. The Routledge History of Literature in English: Britain and Ireland. Fwd. Malcolm Bradbury. London and New York: Routledge, 1997.
}

Histories of literature are necessary. Both students and teachers require them as a guide not only for their courses but also as an indication of the accepted literary cannon and of the critical approach assumed by the academy. The present one is an excellent example of that type of text. It reflects contemporary postmodern views on literary studies including a revision of the cannon that offers, for instance, space for women's voices in all ages, thus acknowledging the importance of literture by women. Together with that the work provides full information about authors, literary movements and the different periods in which they flourished.

It is a book written for a wide audience, probably a global one, as it covers the needs and interests of both native and non-native readership in that cultural, historic and linguistic aspects are analysed in a manner useful for any literature student. One may imagine how difficult it is nowadays to give a title to a work such as the present one, so that it looks like the standard work (the one and only book to be chosen by the market) and, at the same time, it has a mark of distinction that makes it unique. In this case the 
very title shows how "History of English literature" is a phrase that has to be somewhat modified to isolate the literary product offered. This is achieved by means of the publishers' trademark that acts as a guarantee. Moreover, the title is qualified to avoid colonial or anglocentric connotations and the full message of both title and subtitle is that of a reliable, up-to-date, prejudices-free, literary history. The content of this carefully designed book fully strengthens the message included in its emblematic title and matches the prestige of the publisher, as it offers value for money.

Another outstanding feature of this volume is that it is a history of literature in which not only history but also literature is present. This is achieved by means of abundant quotations throughout the text and placed even as well-selected paragraph titles which give the text a literary flavour absent in many other literary histories. The work has a special emphasis on modern and contemporary literature since these are the most widely studied periods of English literature. As it may be seen from the mere space given to the different periods, the twentieth century requires approximately two hundred pages whereas old, middle, and renaissance literature cover little more than a hundred. Obviously, this is due to the quantity of texts preserved from ancient periods, to the importance of the printing press, and to the increase of the reading public that built a whole literary industry in the present century. However, although this is not not necessarily criticizable, one cannot avoid the feeling that the authors have a special interest for modern literature to the detriment of other periods. This may be due to the lack of perspective that we all have about the literary products of our age as they have not yet been filtered through time.

As a whole we can say that we have before us a carefully written work that has all the essential features (including index, Timelines by Jeremy Hunter, and Nobel Prize Winners list) to become a widely considered reference and text book in both schools and universities, useful for students and scholars of English literature throughout the world. It is crystal clear, easy to read and, at the same time, scholarly and accurate in that it faithfully represents the panorama of the literary production of a linguistic community throughout the centuries.

María Jesús Lorenzo Modia

\section{Margaret Atwood. Strange Things: The Malevolent North in Canadian Literature. Oxford: Clarendon, 1995, $126 \mathrm{pp}$.}

This book consists of four lectures delivered by Margaret Atwood at Oxford University in the spring of 1991. In the Introduction Atwood makes it clear that she focuses on the mystique of the Canadian North and its influence on Canadian Literature as a whole, and that she speaks from her position as a non-scholar. To illustrate this, Atwood points out how she tried to match her earrings to the subject matter of each of her lectures; something, she claims, that a respectable academic would not have done.

The first lecture opens up with the problems involved in the definition of the Canadian identity. Atwood states that "the search for the fabled Canadian identity is like a dog chasing its own tail" (8) and this statement shows how the situation has changed since she published Survival in 1972. In the seventies Atwood wrote a book to put Canada in the 